\title{
Defining and Describing What We Do: DoctRINAL LEgAL RESEARCH
}

\section{TERRY HUTCHINSON*}

\author{
Nigel DUNCAN ${ }^{* *}$
}

The practitioner lawyer of the past had little need to reflect on process. The doctrinal research methodology developed intuitively within the common law - a research method at the core of practice. There was no need to justify or classify it within a broader research framework. Modern academic lawyers are facing a different situation. At a time when competition for limited research funds is becoming more intense, and in which interdisciplinary work is highly valued and non-lawyers are involved in the assessment of grant applications, lawyer-applicants who engage in doctrinal research need to be able to explain their methodology more clearly. Doctrinal scholars need to be more open and articulate about their methods. These methods may be different in different contexts. This paper examines the doctrinal method used in legal research and its place in recent research dialogue. Some commentators are of the view that the doctrinal method is simply scholarship rather than a separate research methodology. Richard Posner even suggests that law is 'not a field with a distinct methodology, but an amalgam of applied logic, rhetoric, economics and familiarity with a specialized vocabulary and a particular body of texts, practices, and institutions ...'. 1 Therefore, academic lawyers are beginning to realise that the doctrinal research methodology needs clarification for those outside the legal profession and that a discussion about the standing and place of doctrinal research compared to other methodologies is required.

\footnotetext{
* Associate Professor, Faculty of Law, Queensland University of Technology, Brisbane, Australia. Email correspondence: t.hutchinson@qut.edu.au.

** Professor of Legal Education, City University London, London, United Kingdom. Email correspondence: N.J.Duncan@city.ac.uk. Felicity Deane is the research assistant on this project. We would like to thank those who commented on early drafts of the paper especially Nigel Stobbs, QUT Faculty of Law.

${ }^{1}$ Richard Posner, 'Conventionalism: The Key to Law as an Autonomous Discipline' (1988) 38 University of Toronto Law Journal 333, 345, quoted in Richard Schwartz, 'Internal and External Method in the Study of Law’ (1992) 11(3) Law and Philosophy 179, 185.
} 
The training of lawyers is a training in logic. The processes of analogy, discrimination, and deduction are those in which they are most at home. The language of judicial decision is mainly the language of logic. ... But certainty generally is illusion. ... Behind the logical form lies a judgment as to the relative worth and importance of competing legislative grounds, often an inarticulate and unconscious judgment, it is true, and yet the very root and nerve of the whole proceeding. You can give any conclusion a logical form. You always can imply a condition in a contract. But why do you imply it? It is because of some belief as to the practice of the community or of a class, or because of some opinion as to policy, or, in short, because of some attitude of yours upon a matter not capable of exact quantitative measurement, and therefore not capable of founding exact logical conclusions.

$$
\text { Oliver Wendell Holmes Jnr }{ }^{2}
$$

\section{INTRODUCTION}

With the Global Financial Crisis as a backdrop, it is not surprising that government policy is attempting to direct research money towards whatever is judged to be 'quality' research. Now, more than ever, it is imperative that academic lawyers, working within an increasingly sophisticated research context, explain and justify what they do when they conduct 'doctrinal research'. Lawyers need to explicate their methodology in terminology similar to that used by other disciplines.

The term 'doctrinal research' needs clarification. The word 'doctrine' is derived from the Latin noun 'doctrina' which means instruction, knowledge or learning. The doctrine in question includes legal concepts and principles of all types - cases, statutes, and rules. 'Doctrine' has been defined as '[a] synthesis of various rules, principles, norms, interpretive guidelines and values. It explains, makes coherent or justifies a segment of the law as part of a larger system of law. Doctrines can be more or less abstract, binding or nonbinding. 3 Historically, law was passed on from lawyer to lawyer as a set of doctrines, in much the same way as happened with the clergy. Legal training developed in the middle ages within a religious rhetorical tradition, with the monasteries existing as centres of learning. ${ }^{4}$ The term 'doctrinal' is also closely linked with the doctrine of precedent - legal rules take on the quality of being doctrinal because they are not just casual or convenient norms, but

\footnotetext{
2 'The Path of the Law' (1897) 10(8) Harvard Law Review 457, 465-6.

${ }^{3}$ Trischa Mann (ed), Australian Law Dictionary (Oxford University Press, 2010) 197.

${ }^{4}$ J M Kelly, A Short History of Western Legal Theory (Clarendon Press, 1992) 89.
} 
because they are meant to be rules which apply consistently and which evolve organically and slowly. It follows that doctrinal research is research into the law and legal concepts. This method of research was the dominant influence in $19^{\text {th }}$ and $20^{\text {th }}$ century views of law and legal scholarship and it tends to dominate legal research design. ${ }^{5}$

Where does the doctrinal methodology 'fit' in terms of the spectrum of scientific and social research methodologies used in other disciplines? The doctrinal method lies at the basis of the common law and is the core legal research method. Until relatively recently there has been no necessity to explain or classify it within any broader cross-disciplinary research framework. If we accept that law has a paradigm according to Kuhn's definition, ${ }^{6}$ is a distinct area of scholarship, and that juristic thought in particular makes up part of that discrete and credible paradigm, then it makes sense that law would have its own unique research method. ${ }^{7}$ But therein lies an anomaly for legal researchers. Operate within the intuitive and arcane doctrinal paradigm and you are being vague according to funding providers, operate outside it and you are not being a lawyer according to the profession. At a time when competition for limited research funds is becoming more intense, and when interdisciplinary work is highly valued and non-lawyers are involved in the assessment of grant applications, lawyer-applicants who engage in doctrinal research need to be more open and articulate about their methods.

In the first instance, this article examines the main features of the current Australian and UK research contexts. In particular, it describes the constantly fluctuating government policy frameworks - including the Excellence in Research for Australia (ERA) initiative and the UK Research Excellence Framework (REF) - which are directed towards assuring high quality research outputs. These determine, to some extent, the outcomes for university research funding. This article examines a snapshot of Australian higher degree research (HDR) enrolment and completion statistics for the discipline of law, and very briefly analyses a study of the articulation of research methodologies in recent law theses. The article notes the various

\footnotetext{
${ }^{5}$ Desmond Manderson and Richard Mohr, 'From Oxymoron to Intersection: An Epidemiology of Legal Research' (2002) 6(1) Law Text Culture 159, 161. For a breakdown of empirical and doctrinal PhDs in Australia see Desmond Manderson, 'Law: The Search for Community' in Simon Marginson (ed), Investing in Social Capital (University of Queensland Press, 2002) 152.

${ }^{6}$ Thomas Kuhn, The Structure of Scientific Revolutions (University of Chicago Press, 1962).

${ }^{7}$ C M Campbell, 'Legal Thought and Juristic Values' (1974) 1(1) British Journal of Law and Society 13,15 .
} 
attempts at categorisation, explanation and definition of legal research methodology in the last two decades and describes the standard 'doctrinal' research methodology. This article argues that there needs to be a more overt process for articulating the doctrinal method that is accepted within the discipline and acknowledged outside the discipline. Then, more ambitiously, the article makes a start in attempting the categorisation of this methodology by comparison with other standard 'non-doctrinal' methodologies.

\section{The CuRrent Research LandScAPE}

The research landscape in universities has changed significantly in the last twenty years. There is more emphasis on group, interdisciplinary and empirical research rather than there was under the older paradigm, particularly common in law faculties, of an individual legal researcher working alone. Within the universities, there is an emphasis on increasing links with industry and funded applied research, rather than on purely theoretical research. Governments are encouraging institutional specialisation and centres of excellence, by funding research infrastructure and research training. A 'vocationalist shift' is evident in the promotion of professional doctorates which are more aligned with applied rather than theoretical research.

Competition between law schools for students and research funds is intense. In Australia, the operating grant is no longer 'as of right' but tied to research outcomes and student numbers. In the UK, universities are faced with the withdrawal of government grants to cover teaching; they are now replaced by student fees of up to $£ 9000^{8}$ and intake controls linked to entry qualifications. ${ }^{9}$ In both countries there is an emphasis on success in gaining external competitive grants. The importance of research outputs has prompted a 'publish or perish' mentality. Academics are being directed towards publication in refereed or peer reviewed journals with academic audiences, rather than practitioner journals where, arguably, their research may have more impact. Authoring student texts or disseminating research knowledge to the broader community generally receives less 'kudos'. ${ }^{10}$

\footnotetext{
${ }^{8}$ For the relevant link to the White Paper, see: HEFCE, New arrangements for teaching funding in 2012-13 (2012) <http://www.hefce.ac.uk/learning/funding/201213/>.

${ }^{9}$ For the relevant link to the consultation documents, see: HEFCE, Student number controls for 2012-13 (2011) <http://www.hefce.ac.uk/news/hefce/2011/snc.htm>.

${ }^{10}$ See also Susan Bartie, 'The Lingering Core of Legal Scholarship' (2010) 30(3) Legal Studies 345, 351-2; William Twining 'The SLS Centenary Lecture Punching our Weight? - Legal Scholarship and Public Understanding' (2009) 29(4) Legal Studies 519, 529.
} 
Government funding imperatives do have direct effects on academic research activity. The journal ranking system in Australia is an excellent example of this phenomenon. The influence of the Washington and Lee rankings in formulating ERA law journal rankings resulted in US publications being ranked more highly than several prestigious Australian law journals. This in turn resulted in articles on important jurisdiction-specific legal issues becoming less publishable, and academics directing their research to areas and topics that are more likely to be of interest to international audiences. Because of these unintended results, and the general disquiet in the university sector, the Commonwealth Minister for Innovation, Industry, Science and Research, Senator Kim Carr, suddenly announced at the end of May 2011 that journal rankings were no longer to be a key indicator of research quality for the current ERA process. ${ }^{11}$

There has also been a shift towards a national legal profession in Australia which is accompanied by a trend towards young lawyers practising outside the jurisdiction in which they were trained. ${ }^{12}$ As a result, there is growing recognition of the importance of training in public international and comparative law, and the role legal education plays in internationalising the profession. The movement towards transnational law is being encouraged by the increasing amounts of legal data (case law, legislation, journal articles, law reform reports, parliamentary material, and policy documents) available via the internet, a phenomenon which is, in turn, leading to major changes in doctrinal method. ${ }^{13}$

\footnotetext{
${ }^{11}$ Senator Kim Carr, Minister for Innovation, Industry, Science and Research, 'Ministerial Statement to the Senate Economics Legislation Committee - Improvements to Excellence in Research for Australia (ERA)' (Media Release, 30 May 2011) <http://archive.innovation. gov.au/ministersarchive2011/carr/MediaReleases/Pages/IMPROVEMENTSTOEXCELLENC EINRESEARCHFORAUSTRALIA.html>.

In the UK, reflecting attitudes across Europe, there has been resistance to such formal ranking of journals. However, there is little doubt that journal reputation is of significance at an informal level. Indeed, an attempt has been made to provide a ranking, proposing the Modern Law Review as the pre-eminent journal and six others competing in a second rank (see Kevin Campbell, Alan Goodacre and Gavin Little, 'Ranking of United Kingdom Law Journals: An Analysis of the Research Assessment Exercise 2001 Submissions and Results' (2006) 33 Journal of Law and Society 335, 363; Kevin Campbell et al, 'Journal Publishing, Journal Reputation, and the United Kingdom's Research Assessment Exercise' (1999) 26(4) Journal of Law and Society 470).

${ }^{12}$ See Council of Australian Governments, Attorney-General's Department, National Legal Profession Reform (December 2010) <www.ag.gov.au/legalprofession>.

${ }^{13}$ See, eg, Terry Hutchinson, 'The Transnational Lawyer: GATS, Globalisation and the Effects on Legal Education' (2006) 11(2) Australian and New Zealand Journal of Legal Education 93.
} 
All of these changes are requiring academic lawyers to delineate and defend their research territory. Lawyers need to examine more carefully what it is that they bring to the research table by comparison with the skills, expertise and outputs of other disciplines.

\section{A Research Acknowledged through Government Policy}

Governments in both Australia and the UK have recognised the importance of research for economic development. Their policies have also been influenced by the broader economic picture, particularly the Global Financial Crisis of the last two years. All aspects of university operation are being regulated more directly than ever before in Australia, with the establishment of the Tertiary Education Quality and Standards Agency (TEQSA) and a new Australian Qualifications Framework (AQF), to ensure consistency in accreditation of new courses and high quality outcomes.

In the UK, an incoming Labour government in 1997 increased funding for all aspects of higher education. This increase was administered through the funding councils ${ }^{14}$ and included improvements in core research funding as well as initiatives to improve teaching and learning. This period of relative largesse was curtailed by the global economic crisis and in 2009 the government identified cuts of a total of $£ 398$ million in the Annual Grant for higher education. ${ }^{15}$ A change in government in the UK exacerbated the situation, with a Conservative/Liberal Democrat coalition taking a policy decision to reduce the deficit over a relatively short period. ${ }^{16}$

Research Councils UK argues that 'Continued public investment in scientific endeavour is essential for the success of UK business and industry - and, more broadly, for a productive economy, a healthy society and a sustainable

${ }^{14}$ The Higher Education Funding Councils for England (HEFCE), Wales (HEFCW), Scotland (SFC), and Northern Ireland (NIHEC).

15 Peter Mandelson, Higher Education Funding 2010-11 (22 December 2009) Higher Education Funding Council for England <http://www.hefce.ac.uk/news/newsarchive/2009/ hefcegrantsettlement/>.

16 The Spending Review was announced on 20 October 2010 and indicated a nine per cent reduction in higher education research funding to be placed in the context of a 40 per cent reduction in funding of teaching and student support: see Paul Clark, 'CSR 2010: A Curate's Egg', The Times Higher Education (online), 21 October $2010<\mathrm{http}: / /$ www.timeshigher education. co.uk/story. asp? sectioncode $=26 \&$ storycode $=413961>$; John Morgan, 'Fears Made Flesh: Only STEM Teaching Grants Spared CSR Scythe', The Times Higher Education (online), 20 October $2010<$ http://www.timeshighereducation.co.uk/story.asp?storycode $=413956>$. 
world' ${ }^{17}$ However, these aspirations may be difficult to achieve. Resources available to the Arts and Humanities Research Council ${ }^{18}$ and the Economic and Social Research Council, ${ }^{19}$ the two Councils most likely to allocate grants for legal research, show a projected fall.

The economic downturn appears to have been weathered better in Australia. The 2010 election returned another Labor government. The Tertiary Education Minister, Chris Evans, indicated that 'the Gillard government remains committed to its multi-billion-dollar Bradley reforms despite the need to return to budget surplus in about two years' ${ }^{20}$ The government promised $\$ 5.2$ billion in outlays during the next five to six years including 'improved resourcing of the indirect costs of research'. ${ }^{21}$

Determining the level of funding required to achieve high quality research outcomes is always difficult. Since taking office, Labor has commissioned a number of studies of the university sector. In 2008, the Bradley Review underlined the urgent need for increased funding for Australia's universities. The report concluded that '[f]or Australia to improve its relative performance against other nations, additional, ongoing and significant public investment in higher education will be required'. ${ }^{22}$ December 2008 saw the publication of the Australian House of Representatives Standing Committee Report into Research Training which again pointed to the need for government nurturing of the higher education research sector. ${ }^{23}$ The Report notes the 'years of neglect' of the sector and the 'inadequate funding' as being a 'fundamental

17 Romesh Vaitilingam, Research for Our Future: UK Business Success Through Public Investment in Research (2010) Research Councils UK, $4<\mathrm{http}$ ://www.rcuk.ac.uk/ Publications/reports/Pages/ResearchforourFuture.aspx $>$.

${ }^{18}$ AHRC resources will drop from $£ 99881$ million in 2011/12 to $£ 98370$ million in 2012/13: see Arts \& Humanities Research Council, AHRC Delivery Plan 2011-2015 (December 2010) $19<$ http://www.ahrc.ac.uk/About/Policy/Documents/DeliveryPlan2011.pdf $>$.

${ }^{19}$ ESRC resources will drop from $£ 174637$ million in 2011/12 to $£ 167335$ million in 2012/13: see Economic and Social Research Council, ESRC Delivery Plan 2011-2015, 21 $<\mathrm{http} / / /$ www.esrc.ac.uk/ images/ESRC\%20Delivery\%20Plan\%202011-15 tcm8-13455.pdf>.

${ }^{20}$ Guy Healy, 'Bradley Reforms Go Ahead', The Australian Higher Education, 20 October $2010,21$.

21 Ibid.

22 Denise Bradley (Chair), Australian Government, The Review of Australian Higher Education: Final Report (December 2008), xvii <http://www.deewr.gov.au/highereducation/ review/pages/reviewofaustralianhighereducationreport.aspx $>$.

23 House of Representatives Standing Committee on Industry, Science and Innovation, Parliament of Australia, Inquiry into Research Training and Research Workforce Issues in Australian Universities (1 December 2008) <http://www.aph.gov.au/Parliamentary_ Business/Committees/House_of_Representatives_Committees?url=isi/research/report.htm>. 
obstacle to building Australia's full research capacity'. ${ }^{24}$ It states that '[i]n Australia, we still do not hold research and researchers in high esteem, despite the significant contribution they make to the nation. The low status of research careers is evidenced by continuing low levels of national investment, social recognition and relative remuneration'. ${ }^{25}$ It comments that 'inadequate funding for research training and research careers remains the fundamental obstacle to building Australia's full research capacity'. ${ }^{26}$ A number of recommendations for change came out of this Report. Principally there was a recommendation for increased funding for research and development. ${ }^{27}$

Finally there is the Department of Innovation, Industry, Science and Research Review of the National Innovation System which resulted in the Cutler Report: Powering Ideas: An Innovation Agenda for the 21 st Century. ${ }^{28}$ In this Report the Labor government acknowledged that 'public research capacity is critical' even though ' $[\mathrm{t}]$ he pay-off may be indirect and a long time coming'. ${ }^{29}$ The Report notes that '[w]e depend so much on universities ... that if their performance slips, the whole innovation system suffers. ... Therefore ... [they] must be able to demonstrate genuine and consistent excellence, ${ }^{30}$ These reports recognise the importance of the higher education sector and also the importance to the economy of measuring and encouraging the work being done there.

\section{B Attempts To Measure Research Quality}

In 2008 the Australian federal government announced that the Excellence in Research for Australia (ERA) initiative was to replace the previous government's Research Quality Framework (RQF) program. The UK is also revising its quality review system for higher education. In 2005 the UK government announced that the Higher Education Funding Council for England (HEFCE) would replace the Research Assessment Exercise (RAE) with the Research Excellence Framework (REF) - a more bibliometricsoriented method of assessment, also designed to test economic and social

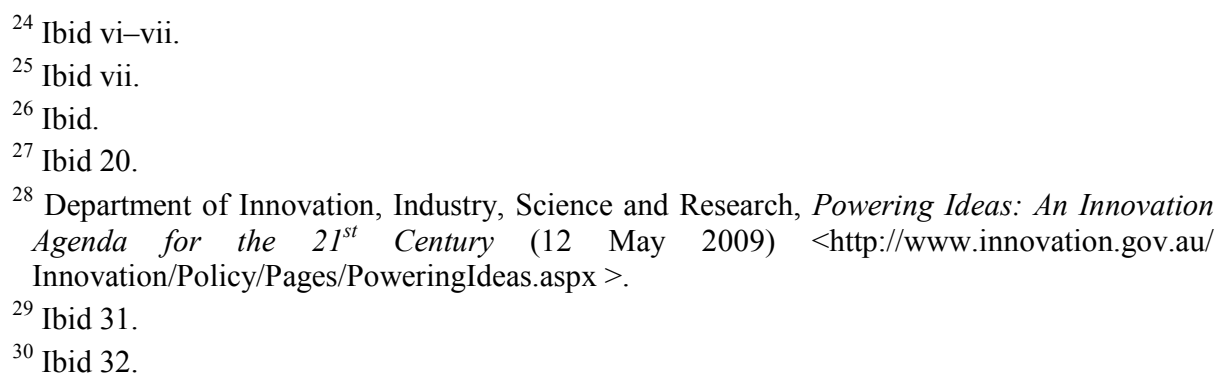


impact. The UK consultation process finished in December 2009 and the first REF exercise is to take place in $2014 .{ }^{31}$ The REF will be undertaken by the four UK higher education funding bodies. ${ }^{32}$ The aim is to reduce the burdensome collection process of the old system while maintaining robust benchmarking.

The primary focus of the UK REF is to identify excellent research of all kinds, assessed through a process of expert review, and informed by robust research citation data. There is significant additional recognition given to researchers who build on excellent research to deliver demonstrable benefits to the economy, society, public policy, culture and quality of life. The emphasis therefore is on research quality, along with effective dissemination and application. This endeavour is administered by four panels, each of which is divided into sub-panels. The Law sub-panel is linked into Panel $\mathrm{C}$ which places it firmly in the company of the social sciences disciplines as opposed to the humanities. ${ }^{33}$

Different criteria are appropriate to different disciplines. A strongly bibliometric approach which may be appropriate in scientific fields of endeavour is not entirely meaningful to lawyers. The use of metrics within the legal discipline is proving highly controversial. Of course, this is because there are no effective metric measures of citation for law. In addition, many in the discipline do not accept that this is a legitimate way to judge the worth of research. Quality of research within the discipline of law is normally

\footnotetext{
${ }^{31}$ HEFCE, Research Excellence Framework <http://www.hefce.ac.uk/Research/ref/>; See also Jayne W. Barnard, 'Reflections on Britain's Research Assessment Exercise' (1998) 48(4) Journal of Legal Education 467; Gareth Williams, 'Misleading, Unscientific, and Unjust: the United Kingdom's Research Assessment Exercise' [1998] (April) British Medical Journal 1079; Paddy Hillyard et al, 'Leaving a Stain upon the Silence' (2004) 44(3) British Journal of Criminology 369.

${ }^{32}$ Higher Education Funding Council for England, Scottish Funding Council, Higher Education Funding Council for Wales, and Department for Employment and Learning, Northern Ireland, Research Excellence Framework Impact Pilot Exercise: Findings of the Expert Panels (November 2010) <http://www.hefce.ac.uk/research/ref/pubs/other/re01 10/>; HEFCE, Research Excellence Framework: Second Consultation on the Assessment and Funding of Research (September 2009) <http://www.hefce.ac.uk/pubs/hefce/2009/09_38/>; Paul Jump 'We Need Impact and the Time to Deliver is Right Now', Times Higher Education, (9 December 2010) 14.

33 Together with Architecture, Built Environment and Planning; Geography, Environmental Studies and Archaeology; Economics and Econometrics; Business and Management Studies; Politics and International Studies; Social Work and Social Policy; Sociology; Anthropology and Development Studies; Education and Sports-Related Studies: see HEFCE, Units of Assessment and Recruitment of Expert Panels (July 2010), $12<\mathrm{http}: / /$ www.hefce.ac.uk/ research/ref/pubs/2010/01_10/01_10.pdf>.
} 
evaluated not only by the citation of research papers by other researchers, but also by the referencing of pertinent research by the courts or law reform bodies. This is not the type of citation measure that is customary for other disciplines. ${ }^{34}$ This category of citation is not included in the most reputable research citation indexes which cover the discipline of law. ${ }^{35}$ Citation rates will continue to be relevant criteria for determining research quality in other discipline areas, so this is a matter of concern to legal researchers.

The Excellence in Research for Australia (ERA) initiative is administered by the Australian Research Council (ARC) and was developed by that body, in conjunction with the Department of Innovation, Industry, Science and Research, to assess research quality using a combination of metrics and expert review by committees comprising experienced, internationally-recognised experts. $^{36}$ These evaluations, similar to the UK REF, are informed by four broad categories of indicators including research quality, research volume and activity, research application and indicators of recognition. Each field is rated on a scale ranging from 1 to $5 .{ }^{37}$ Consultations following the 2010 process

\footnotetext{
34 The AustLII database in Australia has developed a citation measurement system LawCite using the full text judgments and other law reform documents held on the database: see Australasian Legal Information Institute, Law Cite $<\mathrm{http}$ ://www.austlii.edu.au/lawcite/>.

${ }^{35}$ See, eg, Social Sciences Citation Index or Science Citation Index published by Thomson Reuters. The journals indexed in these tend to be published predominantly in the United States. A record of citation including metrics is now available by establishing an individual profile on Google Scholar Citations: <http://scholar.google.com.au/intl/en/scholar/ citations.html>.

${ }^{36}$ Australian Research Council, The Excellence in Research for Australia (ERA) Initiative (24 October 2011) <http://www.arc.gov.au/era/default.htm>.

${ }^{37}$ Australian Research Council, Excellence in Research for Australia 2010 National Report (2011), 5 <http://www.arc.gov.au/pdf/ERA_report.pdf $>$.

But see Jennifer Nielsen, 'Power, Regulation and Responsibility in the Era of ERA Implications for the Emerging Voices of Critical Scholarship' (Paper presented at the Legal Research Interest Group, Annual ALTA Conference, Auckland University, 5 July 2010); Chris Arup, 'Research Assessment and Legal Scholarship' (2008) 18(1\& 2) Legal Education Review 31.
} 
resulted in changes including the removal of journal rankings, proposals to strengthen the peer review process and increased accommodation of multidisciplinary research. ${ }^{38}$

There is some ambivalence as to where law as a discipline 'fits' within the broader research community. ERA evaluates research within 8 discipline clusters. The 2009 trial evaluated the Humanities and Creative Arts (HCA) cluster which contains Law and Legal Studies along with Built Environment and Design, Studies in Creative Arts and Writing, Language Communication and Culture, History and Archaeology, and Philosophy and Religious Studies. ${ }^{39}$ By contrast, Law was in a different social science grouping under the superseded Coalition government Research Quality Framework (RQF) scheme. That previous grouping - with Education and Criminology — was more akin to the present grouping of Law in the UK REF.

In this very competitive context, where discipline funding is based on measurable criteria and outcomes, and where interdisciplinary panels examine their work, it is apparent that academic lawyers need to be able to explain their research in terminology that demonstrates its credentials to those outside law's 'community of practice'. 40

\footnotetext{
${ }^{38}$ Carr, above n 11. See also Kathy Bowrey, Assessing Research Performance in the Discipline of Law: The Australian Experience with Research Metrics, 2006-2011 (Report to the Council of Australian Law Deans, March 2012) documenting the discipline's participation in government-led research performance initiatives.

39 Australian Research Council, 2009 HCA Trial Outcomes (23 June 2011) <http://www. arc.gov.au/era/era_2009/HCA09_trial.htm>.

40 Jean Lave and Etienne Wenger, Situated learning: Legitimate Peripheral Participation (Cambridge University Press, 1991) 98-100; Similar quality measurement schemes are in operation in other jurisdictions: see New Zealand's Performance Based Research Fund: Tertiary Education Commission, Performance-Based Research Fund (4 December 2009) $<$ http://www.tec.govt.nz/Funding/Fund-finder/Performance-Based-Research-Fund-PBRF-/>; Michael Taggart, 'Some Impacts of PBRF on Legal Education' (Paper presented at Keith Conference, Victoria University of Wellington, Wellington New Zealand, 23 August 2007) $<$ http://www.victoria.ac.nz/nzcpl/Files/Keith\%20Conference/Keith\%20Conference\%20$\% 20$ Taggart.pdf $>$.
} 


\section{Competitive Research Funding for Legal Research}

Research published in the United Kingdom in 2004 demonstrates that relatively few projects by UK law school academics in 'core law' research areas were being externally funded. ${ }^{41}$ Michael Doherty and Patricia Leighton defined 'core law' as doctrinal or 'black letter work' ${ }^{42}$ Their study noted that funded projects tended to be 'undertaken by economists, social policy specialists, and those in inter-disciplinary research units that could, but typically do not, involve legal researchers'. ${ }^{43}$

In Australia, as the following graphs demonstrate, an increasing number of ARC Discovery and Linkage Grants Projects, stipulating Law as their primary area, were submitted in the years $2001-2005 .{ }^{44}$ The success rates were higher for the Linkage scheme ${ }^{45}$ than for the Discovery projects. ${ }^{46}$ The Discovery projects are those which are more likely to be using a predominantly doctrinal methodology.

\footnotetext{
${ }^{41}$ Michael Doherty and Patricia Leighton, 'Research in Law: Who Funds It and What Is Funded? A Preliminary Investigation' (2004) 38(2) Law Teacher 182.

${ }^{42}$ Ibid 183. The term 'black letter' refers to research about the law included in legislation and case law. The term originated from the name of the Gothic type which continued to be used for law texts. It is defined in Bryan A Gardner (ed), Blacks Law Dictionary (Westlaw International, $9^{\text {th }}$ ed, 2009) as: 'One or more legal principles that are old, fundamental, and well settled.' In addition, the definition notes: 'The term refers to the law printed in books set in Gothic type, which is very bold and black'.

${ }^{43}$ Doherty and Leighton, above n 41, 198.

${ }^{44}$ Hilary Charlesworth, 'Challenges for Legal Research in Australia' (Paper presented at the Australasian Law Teachers Association Conference, Victoria University of Technology, Melbourne, 4-7 July 2006) 3. 'RFCD' refers to Research Fields, Courses and Disciplines Classification: Australian Bureau of Statistics, Australian and New Zealand Standard Research Classification (ANZSRC) 2008, ABS Catalogue No 1297.0 (2008) $<$ http://www.abs.gov.au/>.

${ }^{45}$ The objectives of Linkage Projects include encouraging and developing long-term strategic research alliances between higher education organisations and other organisations, including with industry and other end-users, in order to apply advanced knowledge to problems and/or to provide opportunities to obtain national economic, social or cultural benefits: see Australian Research Council, Linkage Projects Funding Rules for funding commencing in 2012 Variation (No 1) (19 April 2011), [4.2] <http://www.arc.gov.au/pdf/LP12/lp_funding_ rules_2012_19\%20April\%202011.pdf>.

46 The objectives of the Discovery Projects scheme include supporting excellent basic and applied research by individuals and teams: see Australian Research Council, Discovery Projects Funding Rules for Funding Commencing in 2012 (24 December 2010), [4.2] <http:// www.arc.gov.au/pdf/DP12_fundingrules.pdf $>$.
} 

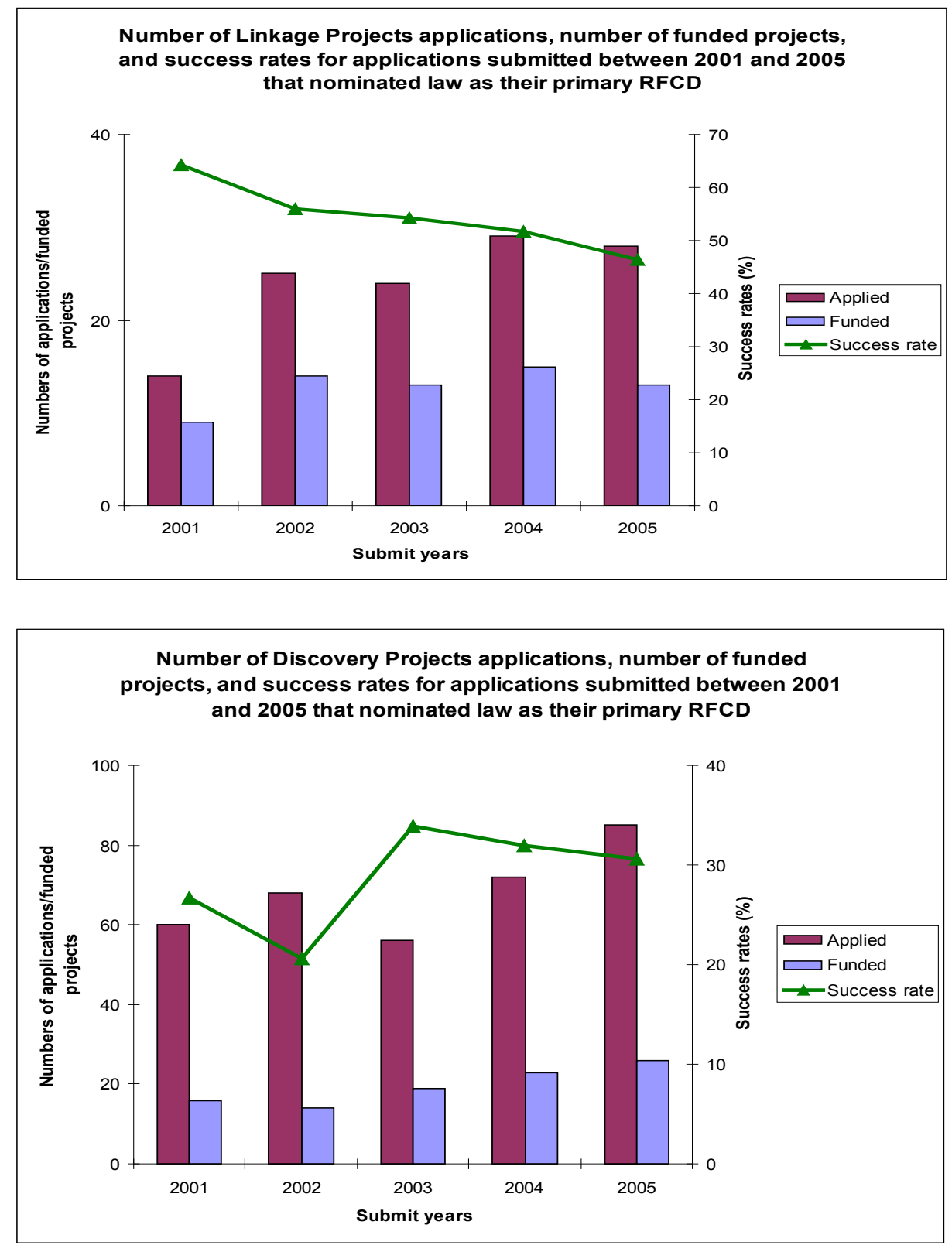
The following table demonstrates the number of applications indicating Law as the primary research area for the years 2002 through to $2009 .{ }^{47}$ The number of applications increased overall but the success rates dropped correspondingly. Success rates in the 'hard sciences' (Engineering and Technology, Biological Sciences, Physical Sciences, Chemical Sciences) were generally higher. ${ }^{48}$ More research is needed to understand the reasons for the failure to achieve higher success rates. The answer may simply arise from two obvious factors - the competition from other high quality projects, together with a finite pot of funds. However, another reason may be that academic lawyers are not explaining the value and quality of their methods with the clarity necessary to satisfy funding bodies' requirements. Further analysis would be required to gauge the influence of the methodology (or lack of a sufficient description of the methodology) on the success of the applications. ${ }^{49}$

ARC Funded Research Projects - Law 3901 50
\begin{tabular}{|l|l|l|l|l|}
\hline & $\begin{array}{l}\text { Number of } \\
\text { applications }\end{array}$ & Number funded & Success rate & Amount \\
\hline 2002 & 47 & 16 & $34 \%$ & $\$ 4501021$ \\
\hline 2003 & 49 & 16 & $33 \%$ & $\$ 2628611$ \\
\hline 2004 & 51 & 17 & $33 \%$ & $\$ 2044181$ \\
\hline 2005 & 53 & 19 & $36 \%$ & $\$ 6037315$ \\
\hline 2006 & 71 & 22 & $31 \%$ & $\$ 5497006$ \\
\hline 2007 & 59 & 13 & $22 \%$ & $\$ 3931606$ \\
\hline 2008 & 68 & 15 & $22 \%$ & $\$ 3770975$ \\
\hline 2009 & 88 & 21 & $24 \%$ & $\$ 8292722$ \\
\hline
\end{tabular}

It is also important to note that in 2009 , while the success rate of applications was lower ( 24 per cent) than, for example, in 2002 (34 per cent), the dollar amount of funding for the year (\$8 292722 ) was considerably higher than in any of the earlier years. Over this time 139 of a possible 485 projects were funded, with a total funding amount of $\$ 36703437$.

\footnotetext{
47 The schemes included are: Centres of Excellence, Discovery Indigenous Researchers Development, Discovery Projects, Federation Fellowships, Australian Laureate Fellowships, Future Fellowships, Linkage Projects (APAI Only), Linkage APD CSIRO, Linkage Infrastructure Equipment and Facilities, Linkage Projects, Special Research Initiatives, Linkage International, ARC Research Networks, and Special Research Initiatives (Thinking Systems): see Australian Research Council, NCGP Statistics - ARC Funded Research Projects Trend Data Sets (April 2010) <http://www.arc.gov.au/xls/WebData Trends.xls\#RFCD_number!A1>.

${ }^{48}$ Ibid.

49 The relative importance of the research methodology and description in determining the success or failure of the applications would evident from the reviewers' assessment scores.

${ }^{50}$ See above n 47.
} 


\section{Examining the Extent of HDR Activity in Australian Law Faculties}

Australian universities have experienced major growth in Higher Degree by Research (HDR) completion rates for Law in the last two decades. Statistics show an increase from a PhD completion rate for Law and Legal Studies in Australia of six students in 1988 to 42 in 1998 (with approximately 20 Masters completions for both years of the study). ${ }^{51}$ The annual figure for 2008 had risen to 79 (together with an additional 16 Masters by Research completions). ${ }^{52}$

Statistics for HDR enrolments in the field of law supplied by the Department of Education, Employment and Workplace Relations (DEEWR) provide a snapshot of the total numbers of students enrolled in HDR courses in Law and Legal Studies (090900-090999) at individual Australian universities each year during the period from 2004 to $2008 .{ }^{53}$ The total enrolments increased from 795 in 2004 to 982 in $2008 .^{54}$ The number of completions is increasing at a slower rate with 85 in 2004 and 95 in $2008 .^{55}$ These statistics demonstrate a discrepancy between the numbers enrolled in higher degrees each year and the annual number of completions. This reflects the lag time between student enrolment and completion. Although doctoral candidates are publicly funded for three years full time, many students would not complete within this timeframe for various reasons. ${ }^{56}$

\footnotetext{
${ }^{51}$ Department of Education Science and Training, Higher Education Report for the 2000 to 2002 Triennium (26 August 2008) <http://www.dest.gov.au/archive/highered/he_report/ 2000 2002/html/3 3.htm>.

52 Department of Education, Employment and Workplace Relations (DEEWR), Selected Higher Education Statistics, Award Course Completions for Detailed Field of Law \& Justice and Law Enforcement Course for Higher Degree Research Students by State/Institution and Level of Course 2004-2008, September 2010. (The Tertiary Cluster of the Department of Education Employment and Workplace Relations has now been transferred to the Department of Industry, Innovation, Science, Research and Tertiary Education.)

${ }^{53}$ Department of Employment and Workplace Relations (DEEWR), Selected Higher Education Statistics, Number of Higher Degree Research, Detailed Field of Law \& Justice and Law Enforcement Courses, Students by State/Institution and Level of Course 2004-2008, September 2010 (Enrolments).

${ }^{54}$ Ibid. The annual figures are 2004 (795), 2005 (849), 2006 (870), 2007 (917) and 2008 (982).

${ }^{55}$ Ibid. These figures include Masters by Research: 2004 (85), 2005 (94), 2006 (81), 2007 (94) and 2008 (95).

${ }^{56}$ According to a quantitative analysis of the performance of the 1992 cohort of postgraduate research students studying at Australian institutions, only 10 completed in the category Law, Legal Studies in the period. See Yew May Martin, Maureen Maclachlan, and Tom Karmel, Department of Education, Training and Youth Affairs, Postgraduate Completion Rates (1999), $21<$ http://www.dest.gov.au/archive/highered/occpaper/01d/01d.pdf >: 'The results
} 
The higher number of students completing at the established universities was commensurate with those institutions' more established postgraduate programs and greater postgraduate student numbers. ${ }^{57}$ Some of the more recently established law HDR programs also demonstrate excellent completion rates despite small enrolment numbers. ${ }^{58}$

These figures paint a picture of a growing Australian university HDR cohort in the fields of Law and Legal Studies. Legal researchers are increasingly being called on to justify and explain (to themselves as well as to those in disciplines which rely largely on empirical methods) the value and importance attached to their work. The increasing numbers of students enrolled in higher degree research in law bodes well for the continued growth of research in the discipline, along with the development of a more sophisticated researcher profile.

\section{E $\quad$ Are HDR Students in Law Articulating Their Methodologies in Their Theses?}

A Higher Degree by Research (HDR) paper stands as evidence of the candidate's research expertise. For this reason, the students, supervisors and examiners need to consider the research methodology that they are using. What data is contained in the research? How was this data collected? At some point there must be a statement, however brief, concerning the method of collection of the data - for example: 'This study will include a doctrinal analysis of legislation and case law.'

Is this sufficient? Should funding agencies, examiners and reviewers expect more detail from legal scholars? Should scholars be including a statement concerning the breadth and depth of the literature, legislation and case law being examined, together with a list of the pertinent issues in proving the argument or thesis? Even accepting that it would be difficult to formulate a thesis without stating the major issues, is it then possible to delineate how

\footnotetext{
indicate that after eight years, only 53 per cent of postgraduate research doctoral students had completed the courses that they had enrolled in 1992', 'The study also confirms the view that few students completed their chosen courses within the expected time. Of those doctoral students who had completed, 36 per cent completed within four full-time study years'.

${ }^{57}$ See above nn 54-5. The University of Melbourne (63 completions in the Law field over the five year period) and the University of Sydney (52 completions in the Law field over the five year period) had by far the largest number of annual HDR student enrolments and completions in the Field of Law tables.

${ }^{58}$ See above nn 54-5. Deakin University, for example, with only a handful of HDR enrolments in the Law field each year, had eight completions in the subject area over the five year period.
} 
these issues are going to be analysed? Is it feasible for doctrinal researchers to describe the legal reasoning techniques being used together with any theoretical underpinnings involved in the analysis? Is it possible to unpack the doctrinal method in this degree of detail?

Unfortunately the doctrinal method is often so implicit and so tacit that many working within the legal paradigm consider that it is unnecessary to verbalise the process. Any articulation that occurs is for the benefit of outsiders. But any discipline could argue the same. It is when lawyers step or are pushed into wider interdisciplinary work, or find themselves competing for grants with researchers from other disciplines, that the articulation of method becomes of paramount importance.

A survey of postgraduate research in Australian law schools undertaken ten years ago demonstrated that only 20 per cent of all doctoral research projects could be described as purely 'doctrinal'. ${ }^{59}$ A more recent examination of HDR theses submitted to the Australasian Digital Thesis Program website in the five year period 2004-9, reveals that most of the legal theses had a doctrinal component, even though only a few students overtly identified the study they were conducting as being to any extent 'doctrinal'. ${ }^{60}$ The analysis covered all law theses from founding universities' law faculties, ${ }^{61}$ together with those from the Queensland University of Technology (QUT). The examination of the database took place in October 2010 and covered a reading of 60 theses available digitally. ${ }^{62}$

\footnotetext{
${ }^{59}$ Manderson and Mohr, above n 5, 164. The term 'doctrinal' was not defined in the study: see also Mann, above n 3, 501.

${ }^{60}$ The study of the Australasian Digital Thesis Program website was undertaken by Felicity Deane and Terry Hutchinson and completed in October 2010: see Council of Australian University Librarians, ADT (Australasian Digital Theses Program) $<$ http://www.caul.edu.au /caul-programs/australasian-digital-theses>.

The Australasian Digital Theses Program database ceased operation in March 2011. The database server has been decommissioned, and the content of that database is searchable via the National Library of Australia's Trove service: <http://www.caul.edu.au/caulprograms/australasian-digital-theses/finding-theses $>$. The ADT included only higher degree theses. Trove includes theses at all levels, including Honours theses. The ADT included only theses from Australian and New Zealand universities whereas Trove includes theses held in other Australian institutions and those awarded elsewhere but housed in Australian libraries.

61 The founding universities are Australian National University, Curtain University of Technology, Griffith University, University of Melbourne, University of New South Wales, University of Sydney, and the University of Queensland.

${ }^{62}$ From the statistics provided earlier in this article, it is obvious that not all theses were placed on the database.
} 
The analysis demonstrates that the doctrinal methodology is rarely discussed, even when a 'methodologies' chapter is included in the thesis. Methodologies' chapters in the theses examined appear more frequently and are more prominent when the thesis involves a survey or interviews. These methodologies ordinarily require ethics clearance from the university but even this crucial step in the research process is not always acknowledged overtly.

An examination of the database demonstrates that only 16 of the 60 theses include a methodologies chapter (26.6 per cent), 21 discuss methodologies as part of another chapter, and one deals with the methodology in an appendix. Therefore, only 38 of the 60 law theses (63.3 per cent) include a discussion of the methodology as part of the thesis. Non-doctrinal methodologies are treated more expansively, with extensive descriptions and lengthy chapters. Where the thesis represents traditional legal research, significantly less, and sometimes no attention is given to explaining the methods used in conducting the research. Fifty-six per cent $(n=34)$ of these legal theses are of a research nature that is unlikely to require ethics clearance. These numbers obviously differ from those in social science disciplines which rely largely on empirical method demonstrating that law is still essentially a 'scholarly' endeavour.

Legal academics may argue that a statement of doctrinal methodology would be out of place in a doctrinal thesis, and that, in any case, this aspect would have been examined during the earlier phases of the HDR process. One commentator, Paul Chynoweth, asserts that 'no purpose would be served by including a methodology section within a doctrinal research publication', because the process is one of 'analysis rather than data collection'. ${ }^{63} \mathrm{We}$ would argue that, while this may be true for published research in journals, the situation in relation to research grant applications and HDR theses is different. Chynoweth argues that legal academics need to seek to educate their interdisciplinary colleagues on the nature of the methodology they use and that, in order to do this, we should 'reflect upon our own previously unquestioned assumptions about the practices in our own discipline, and ... articulate these for the benefit of others within the field'. ${ }^{64}$ On this point we agree entirely.

This small study of a selection of law theses demonstrates that lawyers are not conforming to the formalities of describing methodology in the same way that occurs in other disciplines. Perhaps there is not the same need to articulate the method for an audience from within the law paradigm. However, academic

\footnotetext{
${ }^{63}$ Paul Chynoweth, 'Legal Research' in Andrew Knight and Les Ruddock (eds), Advanced Research Methods in the Built Environment (Wiley-Blackwell, 2008) 37. ${ }^{64}$ Ibid.
} 
lawyers are now participating in broader interdisciplinary environments than they previously did, where there is little knowledge of doctrinal research processes and where there are different expectations in relation to explanations of research methodologies.

\section{Defining Legal Research Terminology}

Before continuing this discussion, it is important to explore some of the nuances implicit in the terminology we are using. We need to distinguish 'law' as a practical discipline exercised within a professional setting, 'law' as a body of normative rules and principles ('the law') and 'law' as an academic discipline. Jurisprudence and law have been a social and political force since the days of the pre-Socratics, but law as an academic discipline did not truly exist in the common law world prior to the late 1800s. ${ }^{65}$ Up until then lawyers received all their training as clerks articled to practising lawyers. This remained true of much legal training in both Australia and the UK right up until the latter half of the twentieth century.

By the 1980s, law was well established as an academic discipline in Australia. At that point, the national review bodies within the tertiary sector began to attempt to define and measure the research work being undertaken in the university law faculties. The Pearce Committee reviewed the research coming out of the Australian law schools. It categorised the research as encompassing:

1. Doctrinal research - 'Research which provides a systematic exposition of the rules governing a particular legal category, analyses the relationship between rules, explains areas of difficulty and, perhaps, predicts future developments.'

2. Reform-oriented research — 'Research which intensively evaluates the adequacy of existing rules and which recommends changes to any rules found wanting.'

3. Theoretical research — 'Research which fosters a more complete understanding of the conceptual bases of legal principles and of the combined effects of a range of rules and procedures that touch on a particular area of activity. ${ }^{66}$

\footnotetext{
${ }^{65}$ David Weisbrot, Australian Lawyers (Longman Cheshire, 1990) ch 5.

${ }^{66}$ Dennis Pearce, Enid Campbell and Don Harding ('Pearce Committee'), Australian Law Schools: A Discipline Assessment for the Commonwealth Tertiary Education Commission
} 
The 1982 landmark study on the state of legal research and scholarship in Canada, the Arthurs Report, included a fourth category covering non-doctrinal methodologies:

4 Fundamental research — 'Research designed to secure a deeper understanding of law as a social phenomenon, including research on the historical, philosophical, linguistic, economic, social or political implications of law. ${ }^{67}$

The Arthurs Report was rather scathing in its assessment of the legal research being carried out in Canada at the time and also commented:

We conclude that law in Canada is made administered and evaluated in what often amounts to a scientific vacuum. Without overstraining analogies to the "hard" sciences, the state of the art of all types of legal research is poorly developed. Clients are advised, litigants represented and judged, statutes enacted and implemented in important areas of community life on the basis of "knowledge" which, if it were medical, would place us as contemporaries of Pasteur, if it related to aeronautics, as contemporaries of the Wright Brothers'. 68

This is an interesting statement that itself might be unpacked a little. In some respects perhaps all that the Committee was saying is what the Nuffield Inquiry has been saying more recently - that we need much more empirical research about the law and its effects in society. ${ }^{69}$

All the reports agreed that doctrinal legal research was the most accepted methodology in the discipline of law. The 2009 CALD (Council of Australian Law Deans) Standards refer to the necessity for students to be able to achieve research methodology skills akin to the 'doctrinal', including:

(Australian Government Publishing Service, 1987) cited in Terry Hutchinson, Researching and Writing in Law (Reuters Thomson, 3rd ed, 2010) 7.

${ }^{67}$ Consultative Group on Research and Education in Law, Law and Learning: Report to the Social Sciences and the Humanities Research Council of Canada (Information Division of the Social Sciences and Humanities Research Council of Canada, 1983) cited in Hutchinson, Researching and Writing in Law, above n 66, 8.

${ }^{68}$ Ibid.

${ }^{69}$ Hazel Genn, Martin Partington and Sally Wheeler, Law in the Real World: Improving our Understanding of HowLaw Works: The Nuffield Inquiry on Empirical Legal Research (The Nuffield Foundation, 2006) <http://www.ucl.ac.uk/laws/socio-legal/empirical/docs/inquiry_ report.pdf $>$. 
a. the intellectual and practical skills needed to research and analyse the law from primary sources, and to apply the findings of such work to the solution of legal problems.

b. the ability to communicate these findings, both orally and in writing. ${ }^{70}$

Martha Minow, Dean of Harvard Law School, in outlining the types of intellectual contribution resulting from legal scholarship, refers to 'doctrinal restatement' and 'recasting' as a starting point for her list:

I Doctrinal Restatement,

a. Organize and reorganize case law into coherent elements, categories, and concepts

b. Acknowledge distinction between settled and emerging law

c. Identify difference between majority and "preferred" or "better" practice - ideally with some explanation for the criteria to be used

II Recasting Project,

a. Gather more than one "line" of cases, across doctrinal fields or categories, and show why they belong together or expose unjustified discrepancies

b. Offer a new framework ...

III Policy Analysis,

a. $\quad \ldots[\mathrm{P}]$ resent a problem; canvass alternatives; propose an evaluative scheme or method; recommend preferred solution ...

IV Test a proposition ...

a. Take a widely assumed or commonly known proposition familiar to lawyers or legal theorists

b. Undertake an empirical investigation about its validity or summarize and assess empirical work conducted by others or undertake model-building or summarize and apply model(s) developed by others ...

V Study, Explain, and Assess Legal Institutions, Systems, or Institutional Actors,

${ }^{70}$ Council of Australian Law Deans, The CALD Standards for Australian Law Schools (17 November 2009), 4 <http://www.cald.asn.au/education>. 
a. [Conduct an] historical, anthropological, sociological or economic analysis of the behavior of legal actors of institutions [utilizing empirical or interpretive methods and/or models]

b. Offer a normative assessment or agenda for further study

VI Critical Projects

a. Expose unstated assumptions, patterns or results, internally inconsistent structures, or other tensions within a body of law or legal practices or institutions

b. Highlight the tensions, [and] contradictions ... [and attempt to link them] to larger psychological, social, or philosophic difficulties ...

VII Comparative and Historical Inquiries,

a. ...[Describe] an earlier era or contrasting legal regime

b. ...[Contextualize the selected era or regime utilizing social sciences such as] anthropology or history

c. ...[Illuminate] differences, choices, or continuities when compared with contemporary domestic practice

VIII Jurisprudence, Philosophy of Law ...

a. Develop or elaborate a theory that tries to explain how ... law or [areas of law fit] together

b. Engage with alternative theories

c. ...Demonstrate the contribution this theory makes to [the resolution of a] doctrinal or practical [problem]

d. Advance [a normative framework for the future]

IX Combinations [of the above-referenced approaches]. ${ }^{71}$

Looking at this issue from a US rather than an Australian or British perspective, Minow canvasses a range of methodologies. In doing so, Minow makes use of the term 'doctrinal' as an accepted term of art, and the process of gaining knowledge from doctrinal work as implicit within the legal research context.

But it is the CALD description which most succinctly delineates the sophisticated higher level thinking which is the hallmark of doctrinal work

\footnotetext{
${ }^{71}$ Martha Minow, 'Archetypal Legal Scholarship - A Field Guide', in AALS Workshop for New Law Teachers (AALS, 2006), 34-5<http://www.aals.org/documents/2006nlt/nltworkbook06. pdf $>$.
} 
and permeates all high quality legal research. The CALD Statement on the Nature of Legal Research reads:

To a large extent, it is the doctrinal aspect of law that makes legal research distinctive and provides an often under-recognised parallel to 'discovery' in the physical sciences. Doctrinal research, at its best, involves rigorous analysis and creative synthesis, the making of connections between seemingly disparate doctrinal strands, and the challenge of extracting general principles from an inchoate mass of primary materials. The very notion of 'legal reasoning' is a subtle and sophisticated jurisprudential concept, a unique blend of deduction and induction, that has engaged legal scholars for generations, and is a key to understanding the mystique of the legal system's simultaneous achievement of constancy and change, especially in the growth and development of the common law. Yet this only underlines that doctrinal research can scarcely be quarantined from broader theoretical and institutional questions. If doctrinal research is a distinctive part of legal research, that distinctiveness permeates every other aspect of legal research for which the identification, analysis and evaluation of legal doctrine is a basis, starting point, platform or underpinning. ${ }^{72}$

Most commentators in this area agree that '[s]ome element of doctrinal analysis will be found in all but the most radical forms of legal research' ${ }^{73}$ The "conceptual analysis of law, ${ }^{74}$ recognised in the CALD Statement, exists as the basis of legal research. Susan Bartie, in examining the scholarship about legal scholarship (what Bartie terms 'legal meta-scholarship'), concluded that 'a great deal of English legal scholarship builds upon the tenets of the core rather than discards them', and that in this regard the 'attitudes towards the core in England and Australia seem almost identical' ${ }^{75}$ Bartie has referred to this research process, with traits "captured by the concept of "doctrinalism" or "black letter law", as "the core tenets of legal scholarship in England and Australia', and has argued that these tenets have provided 'an element of unity in legal scholarship over the past century or so' ${ }^{76}$

\footnotetext{
72 Council of Australian Law Deans, CALD Statement on the Nature of Research (May and October 2005), $3<$ http://cald.anu.edu.au/docs/cald $\% 20$ statement $\% 20$ on $\% 20$ the $\% 20$ nature $\%$ 20of\%20legal\%20research\%20-\%202005.pdf $>$.

${ }^{73}$ Chynoweth, above n 63, 31.

${ }^{74}$ Mann, above n 3, 501.

${ }^{75}$ Bartie, above n 10, 346, 359, 362.

${ }^{76}$ Ibid 345, 350.
} 


\section{A Does the Research Method Differ among the Various Legal Research Genres?}

There are obviously varying degrees of complexity within doctrinal legal research. Doctrinal legal research ranges from practical problem-solving to 'straightforward descriptions of (new) laws, with some incidental interpretative comments', to 'innovative theory building (systematisation)', with 'the more "simple" versions of that research' being the 'necessary building blocks for the more sophisticated ones'. ${ }^{77}$ Different forms of legal research necessitate variations in the method.

There is firstly the problem-based doctrinal research methodology used by practitioners and students. This approach is directed to solving a specific legal problem and normally includes the following steps:

Assembling relevant facts;

Identifying the legal issues;

Analysing the issues with a view to searching for the law;

Reading background material (including legal dictionaries, legal encyclopaedias, textbooks, law reform and policy papers, loose leaf services, journal articles);

Locating primary material (including legislation, delegated legislation and case law;

Synthesising all the issues in context;

Coming to a tentative conclusion.

This type of basic stepped research methodology design can lead to scepticism about doctrinal research in the general academic community. Is doctrinal research simply what 'legal puzzle solvers do' to come up with pragmatic answers? Of course the steps used to research the law are rarely as simple as the list above might suggest.

Even though the practitioner's advice to the client, whether it is verbal or in writing, is invariably concise and pragmatic, it may nevertheless involve very complex aspects of the law. Therefore the practitioner lawyer often specialises

\footnotetext{
${ }^{77}$ Mark Van Hoecke (ed), Methodologies of Legal Research Which Kind of Method for What Kind of Discipline? (Hart Publishing, 2011) vi.
} 
in a particular legal area, and certainly would not need to slavishly follow research steps such as undertaking 'background' reading.

The core doctrinal methodology used by the practitioner is also used by the judge. However, the degree of complexity evidenced in a judge's decision demonstrates another level of doctrinal work. The judge, in determining a case and handing down a decision between opposing parties in the court, is writing not only for the parties and their counsel, but also for a more general audience. The judge's decision needs to be justified and fully explained. The theoretical stance of the judge towards the judicial role, and the approach the judge brings to the reasoning in the case arguably also affects the formulation of the decision. ${ }^{78}$ Of course this decision needs to be determined in conformity to the rules of precedent, and bearing in mind the possibility of more general application of the decision.

Is this all that law academics too are doing when they research? Finding solutions to practical problems? The doctrinal methodology is not always predicated on a specific legal 'problem' or directed to locating one answer or conclusion. Academic researchers choose both the topic and the breadth and depth of investigation. The doctrinal method is similar to that being used by the practitioner or the judge, except that the academic researcher (or HDR student) is not constrained by the imperative to find a concrete answer for a client. As Posner comments:

The messy work product of the judges and legislators requires a good deal of tidying up, of synthesis, analysis, restatement, and critique. These are intellectually demanding tasks, requiring vast knowledge and the ability ... to organize dispersed, fragmentary, prolix, and rebarbative material. ${ }^{79}$

This constitutes the academic lawyer's work.

The researchers' philosophical stance frequently determines the research questions, progress and possible outcomes of academic research. However, the 'perspective' or theoretical stance often lies unstated. Pauline Westerman argues that, within the dominant paradigm, 'the legal system itself functions as a theoretical framework that selects facts and highlights them as legally

\footnotetext{
${ }^{78}$ For example, the declaratory theory, 'law as science', formalism, strict legalism, legal realism and anti-formalism.

${ }^{79}$ Richard Posner, 'In Memoriam: Bernard D. Meltzer (1914-2007)' (2007) 74(2) University of Chicago Law Review 435, 437.
} 
relevant ones'. ${ }^{80}$ Westerman describes the typical approach of academic legal researchers in this way:

Most ... take as a starting-point a certain new legal development, such as a new interpretation of a certain doctrine, or a new piece of European regulation, and just set out to describe how this new development fits in with the area of law they are working in, or, if it does not seem to fit in, how the existing system should be rearranged in order to accommodate for this novelty. So after first depicting what the new development actually consists of, my colleagues commonly address the question of how the new development can be made consistent with the rest of the legal system, in which sense other related concepts are affected and how current distinctions should be adapted and modified. After having described all this, they usually recommend steps in order to accommodate for the new development. $^{81}$

However, while this may hold true for some categories of reform-oriented doctrinal writing, there are many different genres within academic doctrinal work. The treatment of law in a legal encyclopaedia such as Halsbury's Laws of Australia, ${ }^{82}$ or a standard treatise such as Cheshire and Fifoot, ${ }^{83}$ or a practitioner journal such as The Proctor published by the Queensland Law Society, differs markedly from the more broad-ranging discussions taking place in refereed journal articles published in the most prestigious law journals. The HDR thesis constitutes a separate genre. Useful examples of typical HDR statements of main argument or guiding propositions (a device often used as a pseudo-hypothesis within doctrinal academic work) were evident in the theses database: ${ }^{84}$

This dissertation argues that China's legal system must be seen as a product of China's distinctive history and local circumstances. It analyses the current nature of China's corporate disclosure laws and notes that China's law reformers have relied heavily upon the US model which may not necessarily suit China. ... this dissertation argues that China's approach to

\footnotetext{
${ }^{80}$ Pauline Westerman, 'Open or Autonomous? The Debate on Legal Methodology as a Reflection of the Debate on Law' in Van Hoecke, above n 77, 87, 91.

${ }^{81}$ Ibid 89.

${ }^{82}$ LexisNexis, Halsbury's Laws of Australia.

83 Nicholas Seddon and Manfred Ellinghaus, Cheshire and Fifoot's Law of Contract (LexisNexis Butterworths, $9^{\text {th }}$ ed, 2007).

${ }^{84}$ See above $\mathrm{n} 60$.
} 
law reform in this area has not always produced a body of law that is appropriate to China's particular circumstances. ${ }^{85}$

The thesis argues that constitutional recognition and protection of Indigenous rights and the negotiation of treaties are essential if the Indigenous right of self-determination is to be respected and accommodated by the dominant society. ${ }^{86}$

These two examples demonstrate the type of legal research being developed in HDR work. The first deals with the legal system in China, its history and circumstances - a most important topic in terms of the comparative legal system of one of Australia's premier trading partners. This is not a topic which the judiciary or practitioners would ordinarily have the immediate need, time or resources to research, but it is one that any modern lawyer would be interested in reading. It provides context for the internationalisation of commercial practice. Similarly, the topic of the second thesis deals with an important constitutional and social concern with which the Australian government has been grappling for decades. These theses constitute a different level of research to that undertaken in legal practice. In addition, these two examples demonstrate an increased trend towards postgraduate legal scholars formulating clear research questions to explain and justify choices made in the work. ${ }^{87}$

Therefore, although all levels of the profession may be using the doctrinal method, HDR students have different objectives, ask different questions and produce different research outcomes compared to the research undertaken by practitioners and judges. The process and the output of the doctrinal research

\footnotetext{
${ }^{85}$ Jian Fu, Corporate Disclosure by Listed Companies in the People's Republic of China and Australia: Seeking an Appropriate Pathway for the Regulation of the Chinese Securities Market (PhD Thesis, University of New South Wales, 2005), iii <http://www. unsworks.unsw.edu.au/primo_library/libweb/action/dlDisplay.do?vid=UNSWORKS\&docId= unsworks_894>.

${ }^{86}$ Daniel Edgar, The Indigenous Right of Self Determination and 'The State' in the Northern Territory of Australia (PhD Thesis, University of Melbourne, 2008), ii $<$ http://dtl.unimelb.edu.au/R/LTYLPHMJVEF4K3B7AQ7SDRPCCG84EENJ76JL8YI2G44 HV6VKTA-01299?func=dbin-jump-full\&object_id=117935\&pds handle=GUEST $>$.

${ }^{87} \mathrm{H}$ E B Tijssen's thesis noted that 'of the 90 dissertations he investigated ... more than 50 per cent had a clearly formulated research question' to explain and justify choices in the work: Jan B M Vranken, 'Methodology of Legal Doctrinal Research: A Comment on Westerman' in Van Hoecke, above n 77, 118, citing H E B Tijssen, De juridische dissertatie onder de loep. De verantwoording van methodologische keuzes in juridische dissertaties (Legal Dissertations through a Magnifying Glass. Justification of Methodological Choices in Legal Dissertations) (Boom Juridische Uitgevers, 2009).
} 
is different among the various research and writing genres, though facets of the underlying research methodology is similar.

\section{B Doctrinal Method as a Two Part Process}

Doctrinal method is normally a two-part process, because it involves first locating the sources of the law and then interpreting and analysing the text. In the first step, it could be said that the researcher is attempting to determine an 'objective reality', that is, a statement of the law encapsulated in legislation or an entrenched common law principle. ${ }^{88}$ However, many critical legal scholars would be quick to contest whether any such objective reality exists, as the very concept of objectivity is based in a liberal theoretical framework. Most would argue that the law is rarely certain. As Christopher McCrudden comments, '[i]f legal academic work shows anything, it shows that an applicable legal norm on anything but the most banal question is likely to be complex, nuanced and contested' ${ }^{89}$ However, if we take legislation as an example, the laws are passed by parliament and the words are written down. In that sense there is a positive statement of the law. It is at the next step where the law or rule is interpreted and analysed within a specific context that the outcome becomes 'contingent' or conditional on the expertise, views and methods of the individual researcher.

Before analysing the law, the researcher must first locate it. A research project, for example, may require the researcher to access and analyse all the current and historical legislation and administrative regulation of all the Australian states or Canadian provinces for the last century, covering three or four different but related legal subjects, along with any judicial interpretation of those rules and statutes. Even a mere description of the scope of such an exercise makes the breadth of the undertaking more apparent to the 'outsider'.

Having located this wealth of documents, the second step is more nebulous. Is it actually possible to plan and describe this second aspect of the doctrinal research methodology in an intelligible way for an 'outsider'? As Geoffrey Samuel has queried, 'Can legal reasoning be demystified?' ${ }^{90}$ Can the legal

\footnotetext{
${ }^{88}$ Hutchinson, Researching and Writing in Law, above $\mathrm{n}$ 66, 37.

${ }^{89}$ Christopher McCrudden, 'Legal Research and the Social Sciences' [2006] (October) Law Quarterly Review 632, 648.

${ }^{90}$ Geoffrey Samuel, 'Can Legal Reasoning Be Demystified?' (2009) 29(2) Legal Studies 181; Larry Alexander and Emily Sherwin, Demystifying Legal Reasoning (Cambridge University Press, 2008); Geoffrey Samuel, 'Does One Need an Understanding of Methodology in Law before One Can Understand Methodology in Comparative Law?' in Van Hoecke, above n 77, 177.
} 
researcher describe what it is to undertake the distinct form of analysis involved in thinking like a lawyer? Perhaps it is simply the case that the 'medium is the message', ${ }^{91}$ so that the doctrinal discussion and analysis of the law encapsulates and demonstrates the extent of research that has taken place and on which the arguments are based.

The tools at hand can range from 'stare decisis and its complexities' to the 'common law devices which allow lawyers to make sense of complex legal questions' ${ }^{92}$ Those studying the methodologies of lawyers point to a number of techniques used within the synthesizing process once the documents are located and read. They call for a description of the particular line of inquiry being developed, whether it is conceptual, evaluative or explanatory. The application of such techniques, along with a description of, for example, the use of deductive logic, inductive reasoning and analogy where appropriate, would constitute the second part of the methodology. ${ }^{93}$ If the researcher intends to draw heavily on an approach which uses the standard tools of logic, then the methodology would require a description of the basic syllogism and the processes involved in inductive and deductive reasoning. Legal reasoning is often deductive because the general rules are 'given', for example through legislation. The lawyer researcher examines the legislative provision, examines the situation and then decides if the situation comes within the rule. ${ }^{94}$ By comparison, inductive reasoning uses a process of arguing from specific cases to a more general rule. ${ }^{95}$ Where the source of the rule is case law rather than legislation, 'the lawyer will have to examine several cases to find a major premise which underlies them all' ${ }^{96}$ So the lawyer will have to 'reason from particular case decisions to a general proposition'. ${ }^{97}$ Analogy, on the other hand, involves locating similar situations arising, for example, in common law cases, and then arguing that similar cases should be governed by the same principle and have similar outcomes. As Farrar points out, '[a]nalogy proceeds on the basis of a number of points of resemblance of attributes or relations between cases'. ${ }^{98}$ Set out in this way it is apparent that

\footnotetext{
${ }^{91}$ Marshall McLuhan, Understanding Media: The Extensions of Man (Mentor, 1964).

${ }^{92}$ Irene Baghoomians, 'Thinking Like a Lawyer: A New Introduction to Legal Reasoning, by Frederick Schauer' (2009) 31(3) Sydney Law Review 499, 499.

${ }^{93}$ Chynoweth, above n 63, 32; John H Farrar, Legal Reasoning (Thomson Reuters, 2010) 92 quoting Lord Diplock in Dorset Yacht v The Home Office [1970] AC 1004.

${ }^{94}$ Farrar, above n 93, 91.

${ }^{95}$ Christopher Enright, Legal Reasoning (Maitland Press, 2011), ch $6<\mathrm{http}$ //www.legalskills. com.au/>.

${ }^{96}$ Farrar, above n 93, 91.

${ }^{97}$ Ibid.

${ }^{98}$ Ibid 102.
} 
an overtly doctrinal research plan or methodology is feasible, and it would provide a rigour and discipline often missing in doctrinal research. And, as McKerchar argues so succinctly, perhaps this methodology is nothing more than the need for doctrinal research to follow accepted conventions, using clear rationales, and for the research to be 'systematic and purposive with a robust framework'. ${ }^{99}$

\section{$1 \quad$ The Literature Review as a Step within the Doctrinal Method}

One point that must be made is that doctrinal research is more than simply a literature review. ${ }^{100}$ Every research project, no matter what methodology is being used, needs a literature review as a precursor to further study - a nexus to that which has been done before. A literature review routinely includes the following steps:

1. Selecting research questions;

2. Selecting bibliographic or article databases;

3. Choosing search terms;

4. Applying practical screening criteria;

5. Applying methodological screening criteria;

6. Doing the review;

7. Synthesising the results. ${ }^{101}$

The literature review is basically asking: What has been said about the topic previously? What Testimony is available on your topic? ${ }^{102}$ 'Testimony' can include the secondary literature - texts, journal articles, government reports, policy documents, law reform documents and media reports. Just like any

\footnotetext{
99 Margaret McKerchar, Design and Conduct of Research in Tax, Law and Accounting (Lawbook Co, 2010) 116.

${ }^{100}$ Arlene Fink, 'Conducting Research Literature Review: From the Internet to Paper' (Sage Publications, $2^{\text {nd }}$ ed, 2005) cited in Michael McConville and Wing Hong Chui (eds), Research Methods for Law (Edinburgh University Press, 2007) 22-3.

${ }^{101}$ Ibid.

${ }^{102}$ Hutchinson, Researching and Writing in Law, above n 66, 141; Aristotle's Heuristic 'Definition (What is it?) Comparison (What is it like and unlike?) Relationship (What caused it?) Testimony (What has been said about it?) and Circumstance (What can come of it?)'.
} 
other research, doctrinal research requires background research of secondary commentary and sources as a first step. In this respect, doctrinal research requires a literature review, that is, '[a] critical analysis of the existing research literature, theoretical and empirical', related to the research topic. ${ }^{103}$ The literature review thus informs us of 'what is known and not known' about the topic. ${ }^{104}$

But the doctrinal research methodology is much more than 'scholarship'. It is the location and analysis of the primary documents of the law in order to establish the nature and parameters of the law. ${ }^{105}$ That is the crux of the doctrinal method. The 'screening criteria' for legal primary materials are necessarily more rule bound and intricate. Doctrinal research also requires a trained expert in legal doctrine to read and analyse the law - the primary sources: the legislation and case law. Doctrinal research is not simply the locating of secondary information. It includes that intricate step of 'reading, analysing and linking' the new information to the known body of law. ${ }^{106}$ Doctrinal research is centred on the reading and analysis of the primary sources of legal doctrine. It seeks to achieve more than simply a description of the law.

\section{How Can We Categorise the Doctrinal Method vis-à-vis Other Research Methods?}

What kind of discipline is law and how should we categorise its main research method? Legal research does seem to include facets of research methodologies used in other disciplinary domains, including hermeneutic, argumentative, empirical, explanatory, axiomatic, logical and normative techniques. ${ }^{107}$ There seems to be no accepted and stable classification preference for the law discipline within the research schemes. ERA categorises Law within the Humanities and Creative Arts cluster which use qualitative research methods, but more often Law is clustered with the Social Sciences. ${ }^{108}$ The UK REF categorises Law within the Social Sciences Panel and the RQF categorised it in a similar fashion. ${ }^{109}$

\footnotetext{
${ }^{103}$ Maggie Walter (ed), Social Research Methods (Oxford University Press, $2^{\text {nd }}$ ed, 2010) 485.

${ }^{104}$ Ibid.

${ }^{105}$ Hutchinson, Researching and Writing in Law, above n 66, 37.

${ }^{106}$ Ibid 38.

${ }^{107}$ Van Hoecke, above n 77, 4-11.

108 Diana Hacker, Research and Documentation Online <http://www.dianahacker.com/ resdoc/history.html>.

${ }^{109}$ See above $\mathrm{n} 39$ and accompanying text.
} 
One way of describing a process is to ask 'What is it like and unlike?'110 Lawyers have attempted to set the doctrinal method apart and have said that what we do is 'different'. In binary coupling, where the more important term is placed first, academic lawyers privilege the term 'doctrinal' in comparison to 'non-doctrinal'. Anything that is not 'doctrinal' can be encompassed in the 'other' category of non-doctrinal research. Doctrinal method certainly distinguishes itself from 'empirical' or evidence-based methods. Empirical data comes about from 'observing and/or measuring social phenomena'. ${ }^{111}$ There are aspects of 'empirical' or factual notions within doctrinal work, as legislation and judgments may be seen as social phenomena, but these are different because they are 'legitimated' by the sovereignty of the source (parliament or court) rather than because they are the 'naturally occurring', observable phenomena usually used in empirical work. Other terms are bandied around in these discussions, such as quantitative ${ }^{112}$ and qualitative, ${ }^{113}$ which encompass a myriad of research techniques. ${ }^{114}$

\section{$1 \quad$ Comparing Internal and External Research Frameworks}

Some commentators, in discussing the issue of delineation of methodology, have sought to draw a distinction between the 'internal method' which is used in doctrinal legal research and which reflects the viewpoint of the participant in the legal system studying the texts of the law, and the 'external method' which reflects 'the conceptual resources of extralegal disciplines' and involves studying the law in practice using empirical methodologies. ${ }^{115}$

According to Westerman, legal doctrinal research is the type of research which draws on the legal system 'as the main supplier of concepts, categories and criteria'. ${ }^{116}$ This she distinguishes from research that studies law 'from an independent theoretical framework, which consists of concepts, categories and criteria that are not primarily borrowed from the legal system itself' and that

\footnotetext{
${ }^{110}$ Hutchinson, Researching and Writing in Law, above n 66, 141.

${ }^{111}$ Walter, above n 102, 18.

112 Ibid 25. Quantitative research 'involves the collection and analysis of data that can be presented numerically or codified and subjected to statistical testing'.

${ }^{113}$ Ibid 25-6. Qualitative research is 'meaning making' with the key focus being on 'smaller units of people and society, with the method and analyses drawing out the meanings, perceptions and understandings that individuals and groups attach to behaviours, experiences and social phenomena'.

114 Ibid.

115 William Lucy, 'Abstraction and the Rule of Law' (2009) 29(3) Oxford Journal of Legal Studies 481; Hutchinson, Researching and Writing in Law, above n 66, 36.

${ }^{116}$ Westerman, above n 80, 94.
} 
include 'historical studies, socio-legal research, philosophy, political theory and economy'. ${ }^{117}$ As N E Simmonds explains, legal doctrine ('the corpus of rules, principles, doctrines and concepts used as a basis for legal reasoning and justification') represents 'the heart of a legal system' ${ }^{118}$ Simmonds calls the discipline that studies legal doctrine 'legal science': 'Legal science is the systematic and ordered exposition of legal doctrine in the works of juristic commentators'. 119 According to Simmonds, 'Legal science, being itself a body of practices, can be understood only by reference to its own selfconception'. ${ }^{120}$

Similarly, McCrudden explains that the internal method includes the study of law 'using reason, logic and argument' and the 'primacy of critical reasoning based around authoritative texts'. ${ }^{121}$ This internal approach includes the 'analysis of legal rules and principles taking the perspective of an insider in the system'. ${ }^{122}$ This encapsulates the pure doctrinal legal method. As Oliver Wendell Holmes Jr noted in The Common Law, 'The business of the jurist is to make known the content of the law; that is, to work upon it from within, or logically, arranging and distributing it, in order, from its stemmum genus to its infima species, so far as practicable'. ${ }^{123}$ According to this view, the internal aspect of law can be approached in a systematic fashion and the stages documented sufficiently to create a separate doctrinal methodology.

The majority of contemporary legal researchers acknowledge that it is important to build on doctrinal research conclusions by using sociological or other 'outsider' perspectives. The dichotomy that can exist between the study of legal doctrine and actual legal behaviour has been criticised by modern scholars. Roger Cotterrell has argued that true legal scholarship must entail a sociological understanding of law. ${ }^{124}$ But that debate is not central to our

\footnotetext{
${ }^{117}$ Ibid.

${ }^{118}$ Nigel Simmonds, The Decline of Juridical Reason: Doctrine and Theory in the Legal Order (Manchester University Press, 1984) 1.

119 Ibid.

${ }^{120}$ Ibid 30.

${ }^{121}$ McCrudden, above n 88, 633.

${ }^{122}$ Ibid 633; Hutchinson, Researching and Writing in Law, above n 66, 36.

123 Oliver Wendell Holmes Jr, The Common Law Project Gutenberg (December 2000), 219 $<$ http://www.gutenberg.org/dirs/etext00/cmnlw10.txt>.

124 Roger Cotterrell, 'Why Must Legal Ideas be Interpreted Sociologically?' (1998) 25(2) Journal of Law and Society 171.
} 
discussion of legal doctrinal methodology at this point and is not being pursued in this paper. ${ }^{125}$

\section{Is Doctrinal Research a Qualitative or a Quantitative Methodology?}

If we accept that the doctrinal method is a two-part process of locating "the law' or doctrine and then analysing the texts, it might be argued that doctrinal research has aspects of both quantitative and qualitative methodologies within it. Like the quantitative methodologies, doctrinal research is underpinned by positivism and a view of the world where the law is objective, neutral and fixed. The research involved in locating the sources of the law can be easily replicated by other researchers. However, can the law (legislation and case law) be categorised as data? On the contrary, Christopher McCrudden would argue that '[1] aw is not a datum; it is in constant evolution, developing in ways that are sometimes startling and endlessly inventive'. ${ }^{126}$

Many aspects of the law are contingent on context, and need to be interpreted and analysed for meaning. Synthesising the law and, where necessary, applying the law to the facts and context is a highly subjective process. Therefore the analytical, legal reasoning aspect of the process is necessarily a qualitative one. The outcome varies according to the expertise of the individual scholar and cannot be replicated exactly by another researcher. When a researcher undertakes doctrinal work, the outcome is totally dependent on the voice and experience of the individual. Doctrinal research requires a specific language, extensive knowledge and a specific set of skills involving precise judgment, detailed description, depth of thought and accuracy.

As with any social science research, the doctrinal methodology is undertaken according to accepted discipline standards and rules. It requires an ability to achieve a high level of analysis and critique. However, this process is different from social scientific thought. ${ }^{127}$ Doctrinal research focuses on legal principle generated by the courts and the legislature. ${ }^{128}$ Arguments are based on legal norms or standards, and a distinction is made between these standards and the facts of any situation. It differs from other social science research

\footnotetext{
${ }^{125}$ See also Campbell, above $\mathrm{n} 7$.

${ }^{126}$ McCrudden, above $\mathrm{n}$ 89; Hutchinson, Researching and Writing in Law, above n 66, 38.

${ }^{127}$ Campbell, above n 7, 20 citing V Aubert, 'The Structure of Legal Thinking' in F Castberg (ed), Legal Essays (Universitetsforlaget, 1963) 41.

${ }^{128}$ Bartie, above n 10, 350 .
} 
because it involves ' $[t]$ he search for the particular rather than the general' and 'the non-probabilistic nature of statements of law'. ${ }^{129}$

\title{
3 Doctrinal Research Compared to Historical Research
}

Historical research is an example of a methodology that is in some way aligned to doctrinal research. Is doctrinal research a form of or very similar to historical research? Historical research involves

\begin{abstract}
developing an understanding of the past through the examination and interpretation of evidence. Evidence exists in the form of texts, physical remains of historic sites, recorded data, pictures, maps, artifacts, and so on. The historian's job is to find evidence, analyze its content and bias, corroborate it with further evidence, and use that evidence to develop an interpretation of past events that holds some significance for the present. Historians use libraries to: locate primary sources (firsthand information such as diaries, letters, and original documents) for evidence; find secondary sources (historians' interpretations and analyses of historical evidence: verify factual material as inconsistencies arise. ${ }^{130}$
\end{abstract}

Unlike historical research which seeks to find the truth through considering the perspective and view of every actor whatever their social status or role in events, and through examining the whole conceivable range of data, doctrinal research for the most part focuses on 'privileged voices'. ${ }^{131}$ As an example, in doctrinal research, these voices or versions of the truth are those of the judges in case law and the parliament in legislation. The doctrinal researcher is generally not much interested in the transcripts of cases, that is, the dialogue between the barristers and the witnesses. The doctrinal researcher is examining the finding of legal principle. The legal researcher examines primary sources in order to draw logical conclusions about what the law is in those instances where it is not immediately self-evident from those sources. By contrast, the historical researcher examines primary sources as evidence of fact.

\section{Doctrinal Research Compared to Content Analysis}

Content analysis has also been compared to doctrinal research. Is doctrinal research simply a process of analysing a text in a way similar to content analysis? Content analysis has been described as an 'analysis of documents and texts that seeks to quantify content in terms of predetermined categories

\footnotetext{
${ }^{129}$ Campbell, above n 7, 20.

${ }^{130}$ Hacker, above $\mathrm{n} 108,<\mathrm{http}$ //bcs.bedfordstmartins.com/resdoc5e/RES5e_ch05_o.html $>$.

${ }^{131}$ Hutchinson, Researching and Writing in Law, above n 66, 36.
} 
and in a systematic and replicable manner'. ${ }^{132}$ The description 'content analysis' was originally used in connection with quantitative research, but there is a qualitative approach to this methodology that is more frequently used by lawyers. Qualitative content analysis, like doctrinal analysis, emphasizes the role of the investigator in the construction of the meaning of texts. There is 'an emphasis on allowing categories to emerge out of data and on recognizing the significance for understanding the meaning of the context in which an item being analysed (and the categories derived from it) appeared' ${ }^{133}$ Content analysis includes the process of reading judgments, legislation and policy documents as text rather than reading for the substance of the 'law' and legal reasoning. It is the process of quantifying the use of words and then examining the language, and not simply what is being said or the meaning of the words in the first instance. Content analysis identifies patterns in text and the themes in bodies of documents. Critical legal scholars use the technique to identify meaning behind the words of judicial and legislative text. It is a way of deconstructing text rather than reading and synthesising meaning from the text. It is, therefore, distinguished from most doctrinal analysis.

\section{CONCLUSION}

This short examination highlights the need for an increased analysis and description by researchers of the doctrinal methodology they are using. The conclusion from this study is that the doctrinal research methodology is a discrete method. It is more than simply scholarship or an elaborate literature review of primary materials. However, it is not sufficiently delineated for the current research environment. This article has not attempted to fully explain the method, or even to provide a model for researchers to follow in setting out their methodologies. It has proposed the groundwork for the development of such an explanation, in drawing attention to the distinctive characteristics of doctrinal legal research and the characteristics it shares with other research methods. It has argued the need for a thorough examination of the current legal research record and context.

In the past, the under-description of the doctrinal method has not been problematic because the research has been directed 'inwards' to the legal community. The targeted audience has been within the legal paradigm and culture and therefore cognisant of legal norms. However, in a modern interdisciplinary framework, where the research is being directed, read and

${ }^{132}$ Alan Bryman, Social Research Methods (Oxford University Press, $3^{\text {rd }}$ ed, 2008) 692.

${ }^{133}$ Ibid 697. 
more importantly 'judged' by those outside a narrow legally trained discipline, articulation of method is vital - especially if funding is tied to quality, and quality depends on methodological clarity. 